\title{
Cardioprotective Effect of Clarithromycin on Doxorubicin-Induced Cardiac Toxicity in Rats
}

\author{
Mustafa DOGAN ${ }^{1}$, Fatih FIRINCI ${ }^{1}$, Yasemin I. BALCI ${ }^{1}$, Dolunay GURSES ${ }^{1}$, Aziz POLAT ${ }^{1}$, \\ Ozmert MA OZDEMIR ${ }^{1}$, Yasar ENLI ${ }^{2}$, Metin AKBULUT ${ }^{3}$, Barbaros SAHIN ${ }^{4}$ \\ ${ }^{1}$ Pamukkale University Faculty of Medicine, Department of Pediatrics \\ ${ }^{2}$ Pamukkale University Faculty of Medicine, Department of Biochemistry \\ ${ }^{3}$ Pamukkale University Faculty of Medicine, Department of Pathology \\ ${ }^{4}$ Pamukkale University, Faculty of Medicine, Department of Multidicipliner Laboratory, Denizli, TURKEY
}

\begin{abstract}
Doxorubicin is an anthracycline group antibiotic and has long been used as an antineoplastic agent. The most important side effect that limits the usage of doxorubicin is cardiotoxicity, which is observed at cumulative doses. We investigated the protective effect of clarithromycin that is known to have antioxidant and anti-inflammatory effects against Doxorubicin related cardiotoxicity. The aim of our study was to evaluate the effects of clarithromycin in the antioxidant enzyme status and myocardium of doxorobucine-treated rats. A total of 28 adult, male Wistar rats (200-250 g) were divided into 4 groups. Group I was the control group, rats in group 2 were administered doxorubicin, rats in group 3 were administered clarithromycin, and rats in group 4 were administered Doxorubicin + Clarithromycin. Following the scarification of all rats, antioxidant (glutathione) and oxidant (malodialdehyde) levels were measured in the cardiac tissue. Additionally, the cardiac muscles were evaluated histopathologically via hematoxylin eosin staining. The antioxidant amount (glutathione) was significantly higher in the treatment group compared to the doxorubicin group ( $p=0.025)$, whereas the amount of oxidant (malondialdehyde) was significantly lower $(\mathrm{p}=0.022)$. The histopathological examination revealed significant cardiotoxicity in the Doxorubicin group and significant reduction in the cardiotoxicity in the Doxorubicin + Clarithromycin group. The results obtained in this study provide evidence for the usefulness of the clarithromycin as a cardioprotective agent.
\end{abstract}

Keywords: Doxorubicin, Cardiotoxity, Clarithromycin, Rat

\section{ÖZET}

\section{Ratlarda Oluşturulan Doksorubisin'e Bağlı Kardiyotoksisitede Klaritromisinin Koruyucu Etkisi}

Doksorubisin antrasiklin grubu antibiyotiktir ve uzun süredir antineoplastik ajan olarak kullanılmaktadır. Doksorubisin kullanımını kısıtlayan en önemli yan etkisi kümülatif dozlarda gözlenen kardiyotoksisitedir. Antioksidan ve antienflamatuar etkileri bilinen klaritromisinin, doksorubisin ilişkili kardiyotoksisiteye karşı koruyucu etkisini araştırdık. Çalışmamızın amacı doksorubisin ile tedavi edilen ratlarda klaritromisinin myokarda ve antioksidan enzimler üzerine etkilerini değerlendirmektir. Çalışmaya alınan toplam 28 yetişkin erkek Wistar ratı (200-250 g) 4 gruba ayrıldı. Grup 1 kontrol grubuydu, grup 2' de ki ratlara doksorubisin, grup 3' de ki ratlara klaritromisin ve grup 4' e doksorubisin+klaritromisin (tedavi grubu) uygulandı. Skarifikasyonu takiben tüm ratların kalp dokusunda antioksidan (glutatyon) ve oksidan (malodialdehid) düzeyleri ölçüldü. Buna ek olarak myokard dokusu hematoksilen-eozin ile boyanarak histopatolojik olarak değerlendirildi. Antioksidan (glutatyon) miktarı, tedavi grubunda doksorubisin grubuyla karşılaştııldığında önemli derecede yüksekti ( $p=0.025)$, oysa oksidan (malodialdehid) miktarı önemli derecede düşük saptandı ( $p=0.022$ ). Histopatolojik değerlendirmede doksorubisin grubunda ciddi kardiyotoksisite saptanırken doksorubisin + klaritromisin uygulanan grupta kardiyotoksisite de ciddi azalma belirlendi. Bu çalsşmada elde edilen sonuç, klaritromisinin doxorubisine bağlı kardiyotoksitenin engellenmesinde kullanılabilecek kardiyoproduktif etkiye sahip bir ajan olduğudur.

Anahtar Kelimeler: Doksorubisin, Kardiyotoksisite, Klaritromisin, Rat 


\section{INTRODUCTION}

Doxorubicin (DXR) is an anthracycline group antibiotic that is widely used in the treatment of haematological and solid tumours in human since late 1960s. The most feared and usage limiting side effect of DXR is cardiotoxicity. ${ }^{1-3}$ This effect is observed in the cumulative doses. The time of cardiotoxicity onset may depend on the patients. The prognosis of DXR dependent cardiomyopathy is worse than that of ischemic cardiomyopathy. Currently, there is no treatment option other than heart transplantation in the terminal stage treatment of DXR related chronic heart failure. ${ }^{2-5}$ DXR-induced cardiotoxicity is mediated by the formation of free radicals that oxidatively damage many cellular components. ${ }^{1,2,5}$ DXR is enzymatically reduced to its semiquinone radical. ${ }^{6}$ This DXR semiquinone radical directly transfers its electron to molecular oxygen, generating a superoxide radical and hydrogen peroxide. ${ }^{7}$ As reactive oxygen species (ROS) play important roles in DXR-induced toxicity, many compounds with antioxidant properties have been examined as a potential therapeutic and/ or protective agent. Among these compounds were pcoumaric acid ${ }^{8}$, garlic acid ${ }^{1}$, erdosteine ${ }^{5}$, carvedilol ${ }^{2}$, and lycopene. ${ }^{3}$ Many experimental studies have been conducted in order to prevent the cardiotoxic effect of DXR. ${ }^{9-11}$ The agents used in these studies were usually antioxidants that were ceased at the animal study level, and did not take place in the clinical practice. Clarithromycin (CLT), which was used in our study, is U.S. Food and Drug Administration (a-FDA) approved drug with clinical usage and known effects and side-effects. Clarithromycin is a macrolide group antibiotic with a cardioprotective effect

and previously determined anti-inflammatory and antioxidant effects. ${ }^{12-15}$ Clarithromycin suppresses various transcription factors such as activator protein 1 and nuclear factor kappa B. Its cardioprotective, antiinflammatory and antioxidant effects were mediated by the inhibition of proinflammatory cytokine production and matrix metalloproteinase (MMP) activity via suppressing these transcription factors. Based on this effect of clarithromycin, we investigated its mechanism of action in preventing the cardiotoxic effect of DXR. ${ }^{14}$

\section{MATERIALS AND METHOD}

\section{Animals}

Twenty-eight healthy male Wistar albino rats, weigh-

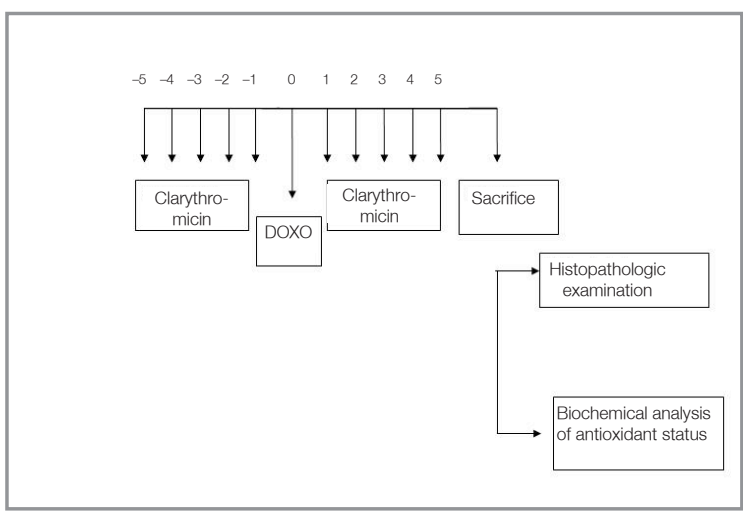

Figure 1. Experimental design of treatment group

ing 200-250 g and averaging 16 weeks old were utilized in this study. The animals were purchased from Pamukkale University Animal Care and Research Unit. Rats were fed on a standard rat chow and tap water ad libitum. In the windowless animal quarter automatic temperature $\left(20-22^{\circ} \mathrm{C}\right)$ and lighting controls were used (12 hour light/12 h dark cycle). Humidity ranged from 50 to $55 \%$. All animals received humane care according to the criteria outlined in the "Guide for the Care and Use of Laboratory Animals" prepared by the National Academy of Sciences and published by the National Institutes of Health. The study was approved by the Institutional Animal Ethical Committee of Pamukkale University, Denizli, Turkey.

Experimental Design: The rats were randomly allotted to one of four experimental groups: control, DOX-treated, only clarithromycin and DOX-treated with clarithromycin; each group contained seven animals (Figure 1)

Experimental Procedures and Sample Collection: Rats were randomly divided into 4 groups; each group included 7 rats. The rats in group 1 were administered a single dose of $5 \mathrm{ml} / \mathrm{kg}$ distilled water intraperitoneally for 10 days (control group). The rats in group 2 were administered a single dose of $5 \mathrm{ml} / \mathrm{kg}$ distilled water for the first 5 days and a single dose of doxorubicine (Adriblastina $50 \mathrm{mg} / \mathrm{mL} /$ Deva/Turkey) $15 \mathrm{mg} / \mathrm{kg}$ in the 6th day intraperitoneally. Then $5 \mathrm{ml} /$ $\mathrm{kg}$ distilled water were given for another 5 days (placebo group). The rats in-group 3 were administered a single dose of clarithromycin (diluted with distilled water) (Klacid, $50 \mathrm{mg} / \mathrm{mL}$, Abbott Laboratories, Istanbul, Turkey) $40 \mathrm{mg} / \mathrm{kg}$ intraperitoneally for 10 days [clarithromycin group]. The rats in group 4 were 


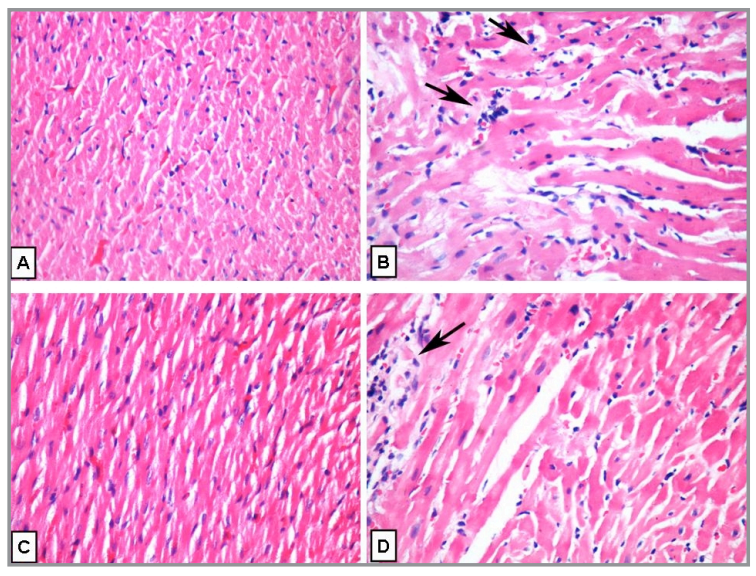

Figure 2. Photomicrograph of the heart tissues of control (a) showing the normal myofibrillar structure with striations and branched appearance. Heart tissues of DXR-treated rats (b) showing focal necrosis of muscle fibers with eosinophilia in the cytoplasm. Heart tissues of DXR-treated rats also show deformations of muscle fibers with focal hemorrhage and inflammatory cell infiltrations (arrows). Rats treated with CLT+DXR (d), exhibiting relatively normal myocardial cells with vascular dilatation and moderate degeneration of some fibril cells. (hematoxylin and eosin, x200.). The heart tissues of clathyromicin group (c) showing the normal myofibrillar structure with striations and branched appearance.

administered clarithromycin $40 \mathrm{mg} / \mathrm{kg}$ diluted with distilled water intraperitoneally for the first 5 days. On the 6th day, a single dose of doxorubicin $15 \mathrm{mg} / \mathrm{kg}$ diluted with distilled water was administered intraperitoneally. Following the administration of doxorubicin, clarithromycine was administered intraperitoneally for an additional 5 days (treatment group). At the end of treatments and after the last clarithromycin and distilled water administration, blood and heart tissues were collected from all groups and stored at $-20^{\circ} \mathrm{C}$ for further processing (Figure 1)

Histopathologic Examination: Heart tissues were harvested from the sacrificed animals, fixed in $10 \%$ neutral formalin and embedded in paraffin blocks. Sections of $5 \mathrm{~mm}$ were obtained, deparaffinized and stained with hematoxylin and eosin. The heart tissue was examined, evaluated and photographed in random order under blind conditions with standard light microscopy (Nikon Optiphot 2, Tokyo, Japan). The severity of changes was quantitated as none (-) to severe (+++) based on the degree of cytoplasmic vacuolization, myocardial disorganization and myofibrillar loss. The scoring system was as follows: $(-)$ no damage, $(+)$ mild, $(++)$ moderate, and $(+++)$ severe damage.
Analysis of Malondialdehyde (MDA) Levels: The levels of 2-thiobarbituric acid-reactive substances (TBARS) were determined following the procedure reported by Ohkawa et al. After thawing, each sample was weighed and homogenized 10 times $(w / v)$ using a $0.15 \mathrm{~N}$ potassium chloride solution (SigmaAldrich); $0.4 \mathrm{ml}$ of homogenate was mixed with 1.5 $\mathrm{ml}$ thiobarbituric acid $(0.8 \%), 1.5 \mathrm{ml}$ acetic acid $(\mathrm{pH}$ : $3.5,20 \%)$ and $0.2 \mathrm{ml}$ sodium dodecyl sulfate $(8.1 \%)$ (Sigma-Aldrich). After mixing, all samples and standards were heated at $100^{\circ} \mathrm{C}$ for $1 \mathrm{~h}$. Absorbance was recorded at $532 \mathrm{~nm}$ and compared with that of the TBARS standards. ${ }^{16}$

\section{Quantification of Reduced Glutathione Levels:}

Reduced glutathione (GSH) was estimated using a modification of the procedure described by Moron et al. as follows: After homogenization of tissue samples with $0.15 \mathrm{~N}$ potassium chloride, $0.5 \mathrm{ml}$ homogenate was mixed with $3 \mathrm{ml}$ of deproteinization solution (sodium chloride, metaphosphoric acid, EDTA, and distilled water) and $1.5 \mathrm{ml}$ potassium chloride solution (SigmaAldrich). Each sample was centrifuged at $1000 \times \mathrm{g}$ for $5 \mathrm{~min}$, and $0.5 \mathrm{ml}$ of the supernatant was added to $2 \mathrm{ml}$ of Na2HPO4 and $0.5 \mathrm{ml}$ of Ellman's reactive (DTNB; dithiodinitrodibenzoic acid, sodium citrate, distilled water) (Sigma-Aldrich Corp). The absorbance of supernatants was recorded at $412 \mathrm{~nm}$ and compared with GSH standards. ${ }^{17}$

\section{Statistical Analysis}

All statistical analyses were carried out using SPSS statistical software (SPSS PASW statistics 18.0). All data are presented in mean $( \pm)$ standard deviations (SD). Dual comparisons between groups exhibiting significant values were evaluated with a MannWhitney U-test. These differences were considered significant when probability was less than 0.05 .

\section{RESULTS}

\section{Histopathological effects on the cardiac tissue}

No pathological change was observed in the histopathological examination of the control or clarithromycin group, whereas significant cytoplasmic vacuolization, myofibrillar disorganization and myofibrillar loss were detected in the DXR group. This negative effects was detected to be significantly decreased in the DXR + clarithromycin group (Table 1) (Figure 2). 
Table 1. Effect of clarrithromycin (clt) on morphological changes as assesed by histopathological examination of heart in the doxorubicine (DXR)-treated rats

\begin{tabular}{|llll|}
\hline GROUPS & Inflammation & Myocardial disorganization & Interstitial fibrosis \\
\hline Control & $(-)$ & $(-)$ & $(-)$ \\
DXR & $(+)$ to $(++)$ & $(++)$ to $(+++)$ & $(+)$ to $(++)$ \\
CLT & $(-)$ & $(-)$ & $(-)$ \\
DXR+CLT & $(-)$ to $(+)$ & $(-)$ to $(+)$ & $(-)$ to $(+)$ \\
\hline$(-):$ none; $(+):$ mild; $(++):$ moderate; $(+++):$ severe & & \\
\hline
\end{tabular}

\section{Effects on the MDA and Glutathione levels in the cardiac muscle}

The MDA level [oxidant system] within the cardiac tissue in DXR group was significantly higher than that of the control $(\mathrm{p}=0.002)$ and clarithromycin groups $(\mathrm{p}=0.008)$, whereas it was not higher in the treatment group than that of the control group $(\mathrm{p}=$ 0.886) (Table 2). The MDA level was significantly lower in the clarithromycin group than the control group $(p=0.014)$. These results indicate once more that clarithromycin has a reductive effect on the oxidant system (Table 2) (Figure 3).

The glutathione [GSH] level within the cardiac tissue in the DXR group was significantly lower than that of the control $(\mathrm{p}: 0,028)$ and clarithromycin groups $(p=0.022)$. However, no significant reduction was observed in the DXR + clarithromycin group compared to the control group with regard to the GSH level $(\mathrm{p}=0.520)$. The GSH level in the clarithromycin group was significantly higher compared to the control group ( $\mathrm{p}=0.022)$. These results indicate the antioxidant effects of clarithromycin (Table 2) (Figure 4).

The antioxidant amount (glutathione) was significantly higher in the treatment group compared to the doxorubicin group $(\mathrm{p}=0.025)$, whereas the amount of oxidant (malondialdehyde) was significantly lower $(\mathrm{p}=0.022)($ Table 2$)$.

\section{DISCUSSION}

In our study, the efficiency of clarithromycin was investigated in the prevention of cardiotoxic effects of DXR. There are many studies that demonstrate the cardiotoxic effects of DXR mediated by oxidative stress. ${ }^{18-21}$

Oxidative stress is an important biological process that is believed to cause severe damage to cell membranes. ${ }^{22}$ Oxidative stress has also been implicated as the major contributing factor to the DXR-induced deformation of heart tissues. ${ }^{2,5,23}$ In the present work, DXR-induced oxidative stress is confirmed by the elevation of oxidized lipids (MDA) .Two different ways of free radical formation by DXR have been described. The first way implicates the formation of a semiquinone free radical by the action of several NADPH-dependent reductases that produce a oneelectron reduction of the DXR to the corresponding DOX semiquinone. In the presence of oxygen, redox cycling of DXR -derived quinone-semiquinone yields superoxide radicals. In the second way, DXR free radicals come from a non-enzymatic mechanism that involves reactions with iron. DXR not only increases free radical production in the tissue, but also decreases its ability to detoxify reactive oxygen species. $^{24}$

DXR reduced the TAC content, Glutatyone and the

\begin{tabular}{|c|c|c|c|c|}
\hline & Control & Doxorubicine & Clarithromycin & Doxorubicine-Clarithromycin \\
\hline Malondialdehyde & $18.07 \pm 1.56^{\mathrm{a}}$ & $21.00 \pm 3.48^{\mathrm{ab}}$ & $14.09 \pm 3.14$ & $17.36 \pm 2.30^{\mathrm{b}}$ \\
\hline Glutathione & $12.25 \pm 3.00^{c}$ & $10.10 \pm 2.36^{\mathrm{cd}}$ & $12.75 \pm 1.93$ & $13.50 \pm 3.26^{d}$ \\
\hline \multicolumn{5}{|c|}{$\begin{array}{l}\text { a: }(p=0.022) \text { comparison between doxo and doxo- clarithromycin groups (MDA) } \\
{ }^{b}:(p=0.025) \text { comparison between doxo and doxo- clarithromycin groups (GSH) } \\
{ }^{c}:(p=0.002) \text { comparison between control and doxo groups (MDA) } \\
{ }^{d}:(p=0.028) \text { comparison between control and doxo groups (GSH) }\end{array}$} \\
\hline
\end{tabular}




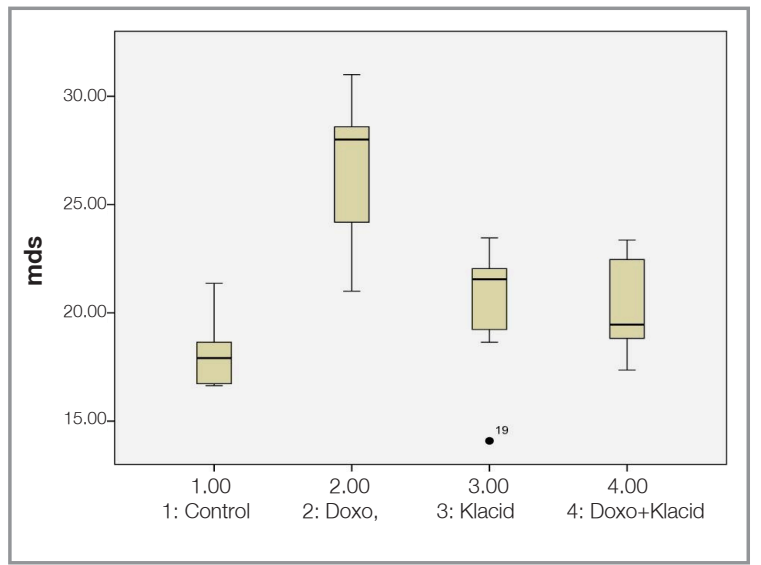

Figure 3. Comparison with MDA levels in groups.

antioxidant activity of SOD enzyme in the heart.Free radicals have been shown to exhaust the antioxidant defence system and hence elevate the oxidation process of both lipids and proteins in heart tissues of DXR-treated rats. ${ }^{2,5,23}$ In accordance with the previous studies, the glutathione level was found to be reduced in the DXR treatment group of our study as well, due to the increased functioning of the antioxidant system in order to compensate the oxidative stress and related increase in the consumption of glutathione. ${ }^{23}$

DXR has been reported to cause cardiomyopathy in various animal species $[3,4]$. Similarly to many other studies, the DXR-induced myocardial damage reported here was associated with clear myocardial histopathological lesions (myocyte necrosis, degeneration, and inflammatory cell infiltrations), ${ }^{3,4,5,25}$ Similar to these studies, significant cytoplasmic vacuolization, myofibrillar disorganization and myofibrillar losses were observed in the histopathological examination of the cardiac tissues in the DXR administered rats compared to the control group, in our study.

There are many other studies demonstrating the antioxidant and anti-inflammatory effects of clarithromycin. ${ }^{12-15}$ Recent studies show that this macrolide antibiotic has anti-inflammatory activity, which likely depends on its ability to prevent the production of proinflammatory mediators and cytokines, and suggest that this agent can exert therapeuticeffects independent of its antibacterialactivity. ${ }^{12-15}$ The MDA level was significantly decreased and GSH level was significantly increased in the clarithromycin group compared to the control group in our study. The MDA level was significantly decreased and the GSH level was significantly increased in the treatment group compared to the DXR group. These results are evi-

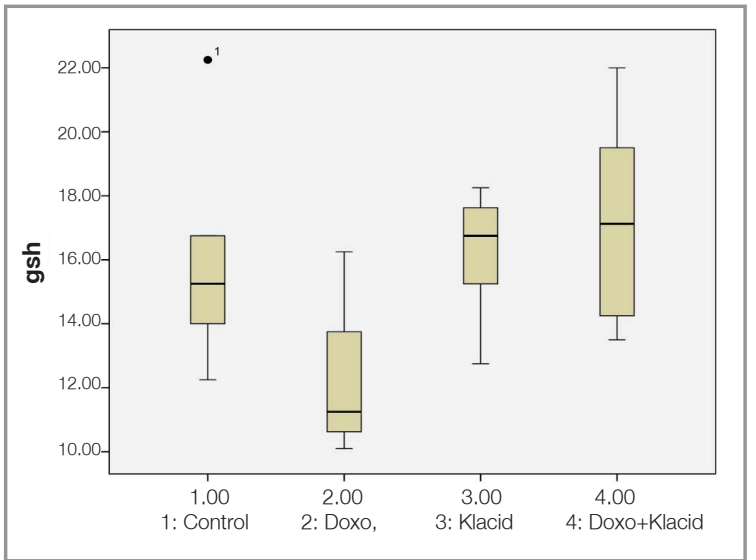

Figure 4. Comparison with GSH levels in groups.

dences of the antioxidant effects of clarithromycin.

The cardiotoxic effect in the treatment group was shown significantly reduced at a histopathological level compared to the DXR group. Based on these results, the cardioprotective effect of clarithromycin against DXR was evidently demonstrated at a histopathological level.

Cardiotoxic effect of Clarithromycin is rarely seen as ventricular arytmia and torsades de pointes in patients with long QT syndrome, but it does not have toxic effects on cardiac functions. In 2010, Guo D et al. published a review of 48 patients reported in literature. Eighteen of those 48 patient were reported as clinical study and 30 of them reported as case report and it was reported that all of those patients has had long QTc syndrome as adverse effect. In this review, it was reported that advanced age, high dosage, fast application of drug and concomitant cardiac pathology increase cardiac toxicity. Lack of our study is, we could not take ECG records of rats. However to prevent the doxorubicin toxicity klaritromisin usage with ECG recordings before and after drug admission could be more appropriate. ${ }^{26}$

Many herbal agents that are known to be antioxidants have been used in previous studies in order to reduce the cardiotoxic effects of doxorubicin, and positive results were obtained. ${ }^{27}$ However, none of these agents were introduced in the medical usage, and therefore, the positive and negative effects on human are not clearly understood. Thus, these agents could only reach the animal study level., ${ }^{3,528}$ Clarithromycin on the other hand, is an antibiotic with known antioxidant and anti-inflammatory effects for a long time. Therefore the effects and side effects of the drug is clearly known. We believe that clarithromycin 
is a more proper agent compared to the agents used in other studies due to this effect. As a conclusion, clarithromycine is a directly effective drug in the prevention of DXR related cardiotoxicity.

\section{REFERENCES}

1. Mukherjee S, Banerjee SK, Maulik M, et al. Protection against acute adriamycin-induced cardiotoxicity by garlic: role of endogenous antioxidants and inhibition of TNF-alpha expression. BMC Pharmacol 3: 16-24, 2003.

2. Oliveira PJ, Bjork JA, Santos MS, et al. Carvedilol-mediated antioxidant protection against doxorubicin-induced cardiac mitochondrial toxicity. Toxicol Appl Pharmacol 200: 159-168, 2004.

3. Yilmaz S, Atessahin A, Sahna E, Karahan I, Ozer S. Protective effect of lycopene on adriamycin-induced cardiotoxicity and nephrotoxicity. Toxicology 218: 164-171, 2006.

4. Fujimura L, Matsudo $\mathrm{Y}$, Kang M, et al. Protective role of $\mathrm{Nd} 1$ in doxorubicin-induced cardiotoxicity. Cardiovasc Res 64: 315321, 2004.

5. Yagmurca M, Fadillioglu E, Erdogan $\mathrm{H}$, et al. Erdosteine prevents doxorubicin-induced cardiotoxicity in rats. Pharmacol Res 48: 377-382, 2003.

6. Minotti G, Parlani M, Salvatorelli E, et al. Impairment of myocardial contractility by anticancer anthracyclines: role of secondary alcohol metabolites and evidence of reduced toxicity by a novel disaccharide analogue. Br J Pharmacol 134: 1271-1278, 2001.

7. Gille L, Nohl H. Analyses of the molecular mechanism of adriamycin-induced cardiotoxicity. Free Radic Biol Med 23: 775$782,1997$.

8. Abdel-Wahab MH, El-Mahdy MA, Abd-Ellah MF, et al. Influence of p-coumaric acid on doxorubicin-induced oxidative stress in rat's heart. Pharmacol Res 48: 461-465, 2003.

9. Cao Y, Kennedy R, Klimberg VS. Glutamine protects against doxorubicin-induced cardiotoxicity. J Surg Res 85: 178-182, 1999.

10. Sarvazyan NA, Askari A, Huang WH. Effects of doxorubicin on cardiomyocytes with reduced level of superoxide dismutase. Life Sci 57: 1003-1010, 1995.

11. Viswanatha Swamy AH, Wangikar U, Koti BC, et al. Cardioprotective effect of ascorbic acid on doxorubicin-induced myocardial toxicity in rats. Indian J Pharmacol 43: 507-511, 2011.

12. Amsden GW. Anti-inflammatory effects of macrolides--an underappreciated benefit in the treatment of community-acquired respiratory tract infections and chronic inflammatory pulmonary conditions? J Antimicrob Chemother 55: 10-21, 2005.

13. Ding FM, Zhu SL, Shen C, Jiang YQ. Low-dose clarithromycin therapy modulates CD4(+) T-cell responses in a mouse model of chronic Pseudomonas aeruginosa lung infection. Respirology 17: 727-734, 2012.

14. Ianaro $A$, lalenti $A$, Maffia $P$, et al. Anti-inflammatory activity of macrolide antibiotics. J Pharmacol Exp Ther 292: 156-163, 2000.
15. Ozdemir OM, Ergin H, Yenisey C, et al. Protective effects of clarithromycin in rats with hypoxia/reoxygenation-induced intestinal injury. J Pediatr Surg 45: 2169-2174, 2010.

16. Ohkawa H, Ohishi N, Yagi K. Assay for lipid peroxides in animal tissues by thiobarbituric acid reaction. Anal Biochem 95: $351-$ 358, 1979.

17. Moron MS, Depierre JW, Mannervik B. Levels of glutathione, glutathione reductase and glutathione S-transferase activities in rat lung and liver. Biochim Biophys Acta 582: 67-78, 1979.

18. Geetha A, Sankar R, Marar T, Devi CS. Alpha-tocopherol reduces doxorubicin-induced toxicity in rats--histological and biochemical evidences. Indian J Physiol Pharmacol 34: 94-100, 1990.

19. Mohan IK, Kumar KV, Naidu MU, et al. Protective effect of CardiPro against doxorubicin-induced cardiotoxicity in mice. Phytomedicine 13: 222-229, 2006.

20. Mohamed HE, El-Swefy SE, Hagar HH. The protective effect of glutathione administration on adriamycin-induced acute cardiac toxicity in rats. Pharmacol Res 42: 115-121, 2000.

21. Singal PK, Siveski-lliskovic N, Hill M, et al. Combination therapy with probucol prevents adriamycin-induced cardiomyopathy. J Mol Cell Cardiol 27: 1055-1063, 1995.

22. Sorg O. Oxidative stress: a theoretical model or a biological reality? C R Biol 327: 649-662, 2004.

23. Dalloz F, Maingon $P$, Cottin $Y$, et al. Effects of combined irradiation and doxorubicin treatment on cardiac function and antioxidant defenses in the rat. Free Radic Biol Med 26: 785800, 1999.

24. Kalender Y, Yel M, Kalender S. Doxorubicin hepatotoxicity and hepatic freeradical metabolism in rats. The effects of vitamin $E$ and catechin. Toxicology 209: 39-45, 2005.

25. Breitbart E, Lomnitski L, Nyska A, et al. Effects of water-soluble antioxidant from spinach, NAO, on doxorubicin-induced heart injury. Hum Exp Toxicol 20: 337-345, 2001.

26. Guo D, Cai $Y$, Chai $D$, et al. The cardiotoxicity of macrolides: a systematic review. Pharmazie 65: 631-640, 2010.

27 Dorr RT. Cytoprotective agents for anthracyclines. Semin Oncol 23: 23-34, 1996.

28 Kimura T, Fujita I, Itoh N, et al. Metallothionein acts as a cytoprotectant against doxorubicin toxicity. J Pharmacol Exp Ther 292: 299-302, 2000

\section{Correspondence}

Dr. Mustafa DOĞAN

Pamukkale Üniversitesi

Pediatrik Kardiyoloji Anabilim Dalı

Kınıklı

DENIZLI / TURKEY

Tel: (+90.258) 2965415

e-mail: mustafad42@gmail.com 